G.S.Zhetessova, Dr. Sc. (Tech.), Prof., orcid.org/0000-0001-6504-3405, O. M. Zharkevich, Cand. Sc. (Tech.), Assoc. Prof., orcid.org/0000-0002-4249-4710,

O.A. Nurzhanova,

orcid.org/0000-0002-0984-9284,

D.S.Zhunuspekov,

orcid.org/0000-0002-3922-738X
Karaganda State Technical University, Karaganda, the Republic of Kazakhstan, e-mail: zharkevich82@mail.ru

\title{
FIT SELECTION AND LIFE FORECASTING OF WORK OF MOVABLE JOINTS OF HYDRAULIC PROPS OF POWERED SUPPORTS
}

Purpose. To determine dependencies of structural parameters taking into account the impact of dynamic processes and the phenomenon of wear in movable joints of hydraulic props of powered supports to increase the life of their work.

Methodology. In this work, the method of analogues and the calculation method were used during fit selection, dimensional analysis was used when developing a gap formation scheme in a piston joint of a hydraulic prop of a powered support. The least squares method was used to determine the empirical dependence of movable joints of hydraulic props of powered supports on the minimum structural gap and assurance coefficient of joint mobility.

Findings. A technique was developed that enables to forecast the life of movable joints and hydraulic props, in general, depending on the quality of production, operating conditions and materials of parts. Recommendations were developed that increase the efficiency of hydraulic props of powered supports.

Originality. Expressions were obtained to determine the minimum and maximum structural gaps in movable joints of hydraulic props, taking into account the wave dynamics of rock bursts and the wear of surfaces of conjugated parts during friction contacts in the work process of powered supports.

Practical value. A procedure was developed to calculate the structural gap for forecasting the operational life of movable joints of hydraulic props.

Keywords: powered support, gap, hydraulic prop, wear, rock burst

Introduction. Transition of mining operations to large depths, as the global experience in the exploitation of coal and ore deposits shows, is accompanied by an increase in the complexity of mining and geological conditions: the number of layers with hard roofs is increasing; dynamic rock pressure manifestation is accompanied by emissions of coal, gas, rock and rock bursts [1, 2], as well as the action of transverse and eccentric forces. The use of serial mechanized complexes under these conditions does not fully ensure safety and efficiency of second workings due to the severe aftermath of dynamic effect at the moment of sudden roof collapse. A decrease in the actual resistance of hydraulic props and, as a result, in the sections of powered supports in general causes an increase in putting-downs of pull-out parts of hydraulic props, up to their fit "hard", with all the ensuing consequences.

During sharp settlements of thick layers of the main roof, i.e. during dynamic application of an external load with a speed of up to $0.5 \mathrm{~m} / \mathrm{s}$ and above, a pressure surge in head ends of hydraulic props can reach $140 \mathrm{MPa}$ [3]. At the same time, a water hammer phenomenon is possible, which can lead to residual deformations of cylinder walls, solidifications and other support elements and the destruction of hydraulic props.

Literature review. Hydraulic prop is subjected to loads, as a result of which radial deformations cause a

(C) Zhetessova G.S., Zharkevich O.M., Nurzhanova O.A., Zhunuspekov D.S., 2019 gap between a piston and a cylinder, which influences the solidification efficiency [4], and, as a consequence, tightness.

In the working process of hydraulic props their elements are movable relative to each other, and the gaps between them are set based on the need to preserve the movable gatherings in the conjugations of the pistoncylinder and rod-bushing pairs [5]. Due to gaps in such joints, in spite of the existing filters for cleaning working fluid, solid particles with sizes up to 80 microns are present in hydraulic systems [6]. They destroy the surface of the elements of hydraulic props. Friction effects for the elements of hydraulic props are aggravated by the impact of aggressive underground environment and the danger of water hammers.

Purpose. The need to increase the efficiency of hydraulic props of powered supports determines the fulfillment of accuracy requirements in the form of the accuracy characteristics of their elements. For efficient operation of hydraulic props during the life (at least 20.000 hours before the first overhaul) of a specified SS 18585 -73 , it becomes necessary to narrow tolerances for the manufacture of movable joints of hydraulic props.

The main part. Taking into account the influence of $d y$ namic processes in the elements of hydraulic props. With the probable possibility of rock bursts, the calculation of slide fit in the joints of hydraulic props must be carried out taking into account the dynamics of gaps change and the need for free movement of parts with large radial deformations caused by stress waves of considerable amplitude. 
With complex configurations of parts, as a result of the reflection of stress waves from the boundaries of changes in acoustic rigidity and their interference with direct waves, a complex stress field is formed at each point of the part, varying not only from section to section, but also in each section with time. Therefore, deformations in each section should be considered as a sum of successive shock waves, such as longitudinal and transverse ones, direct and reflected ones, Rayleigh surface waves, and others [7]. In structures of hydraulic props of powered supports, parts (pistons, bushings, rods, etc.) have a complex structural form. In this regard, the shape of shock pulses formed by the collisions of these parts is very complex. Numerous partial reflections and passages of the initial wave, arising upon impact, cause changes in cross sections [8].

Let us reduce a design model of the study of wave activity in hydraulic props of powered supports (Fig. 1).

For a limit case, when during the interference direct and reflected waves have the same sign [9], the maximum stress in details loaded with an impact is determined by the expression

$$
\sigma_{\max }=\left(0.35 \frac{e}{\sqrt{J / F_{g}}}+\frac{1+r_{1}}{2} K_{f}\right) \cdot \frac{\vartheta_{0}}{a} \cdot E,
$$

where $e$ is the size of a gap due to a movable fit, m; $J$ is the moment of inertia of a rod section, $\mathrm{m}^{2} ; F_{g}$ is the cross-sectional area of a part with which a rod collides (according to the design model, this is the area along the bolster of a column bed), $\mathrm{m}^{2} ; V_{0}$ is the impact velocity, assumed to be equal to the velocity of a roof settling, $\mathrm{m} / \mathrm{s} ; r_{1}$ is the coefficient of stress waves; $K_{f}$ is the coefficient taking into account the ratio of the sections involved in the impact of parts; $E$ is the modulus of elasticity, MPa; a is the wave velocity in colliding parts, $\mathrm{m} / \mathrm{s}$.

In turn, the coefficient of stress waves is determined by the formula

$$
r_{1}=\frac{F_{1-} F_{g}}{F_{1}+F_{g}}
$$

where $F_{1}$ is the rod section area.

Coefficient $K_{f}$ is determined by the formula

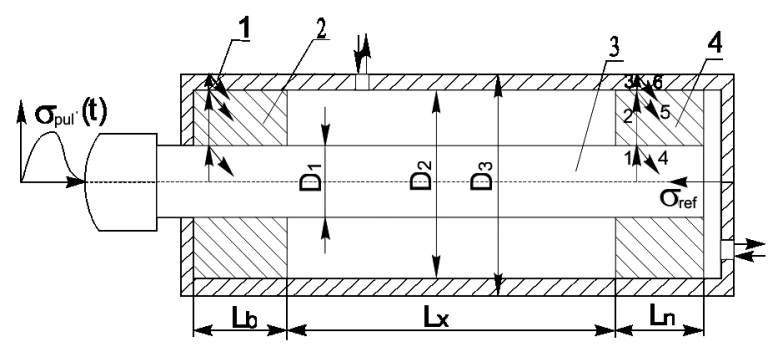

Fig. 1. Design model of a hydraulic prop:

1 -cylinder; 2 - bushing; 3 - rod; 4 - piston; $L_{6}$ - bushing length; $L_{x}-$ stroke length; $L_{n}-$ piston length; $d_{1}-$ piston diameter; $d_{2}-$ inner diameter of the cylinder; $d_{3}-$ outer diameter of the cylinder

$$
K_{f}=\frac{2 F_{1}}{F_{1}+F_{g}}+\frac{4 F_{1} \cdot F_{g}}{\left(F_{1}+F_{g}\right)^{2}} \cdot \frac{F_{2}-F_{1}}{F_{2}+F_{1}},
$$

where $F_{2}$ is the area that perceives the stress wave reflected after an impact.

A stress wave passed from a rod through a joint to a piston along an arrow 2 has amplitude [9]

$$
\sigma_{p}=\sigma_{\max } \cdot Q_{c 1} \cdot \frac{F_{k 1}}{F_{p}}
$$

where $Q_{c 1}$ is the coefficient of passing of an elastic wave through a joint; $F_{k 1}$ is the cylinder section area, $\mathrm{m}^{2} ; F_{p}$ is the piston section area, $\mathrm{m}^{2}$.

A part of this wave with an amplitude $\sigma_{p}$ passes to the second joint along arrow 3 into the cylinder

$$
\sigma_{c}=\sigma_{p} \cdot Q_{c 2} \cdot \frac{F_{k 2}}{F_{c}},
$$

where $Q_{c 2}$ is the coefficient of passing of an elastic wave through a joint; $F_{k 2}$ is the piston section area, $\mathrm{m}^{2} ; F_{c}$ is the cylinder section area, $\mathrm{m}^{2}$.

Part of the wave with an amplitude $\sigma_{\text {ref }}$ is reflected from the "piston-cylinder" border back to the piston along arrow 5

$$
\sigma_{r e f}=\sigma_{n} \cdot R_{c 2},
$$

where $R_{c 2}$ is the coefficient of dynamic reflection of the stress wave in this joint.

The essence of parameters included in the last formulas $(1-3)$ and the methods for their determination are described by following formulas.

Coefficient $Q_{c}$ can be calculated by the formula

$$
Q_{c}=\frac{2 F_{k} \rho_{c} b}{F_{k} \rho_{c} b+F_{y} \rho_{y} a_{y}},
$$

where $F_{k}$ is the actual contact area of conjugated rough surfaces, $\mathrm{m}^{2} ; F_{y}$ is the section area, loaded with an impact of a part, $\mathrm{m}^{2} ; \rho_{y}$ and $\rho_{c}$ is the density of materials of a part loaded with an impact and conjugate to it along a fit $\mathrm{kg} / \mathrm{m}^{3} ; b$ is shear (transverse) wave velocity, $\mathrm{m} / \mathrm{s} ; a_{y}$ is longitudinal wave velocity in a part loaded with an impact, $\mathrm{m} / \mathrm{s}$.

The velocity of the transverse wave is determined by the formula [9]

$$
b=\sqrt{\frac{E}{2(1+\mu) \rho}},
$$

where $\mu$ is Poisson's ratio.

Velocity of the longitudinal wave in a part loaded with an impact is determined by the formula

$$
a=\sqrt{E / p} .
$$

The coefficient of dynamic reflection of the stress wave when passing through a joint is determined by the formula

$$
R_{c}=1-Q_{c}
$$


The transverse stress wave loads covering and other parts in contact with the colliding parts with impact impulses, and has an amplitude of

$$
\tau=\sigma_{p u l}(t) Q_{c} .
$$

In this regard, all the parts entering the joint change their diametrical and linear dimensions in proportion to the value of stress waves passing through them [10]. The simultaneous deformation of both parts of the joint, a part loaded with an impact and a conjugated part, leads to a significant increase in a gap in dynamics (Fig. 2).

The value of change in a gap in the joint loaded with an impact can be determined using (4), by the formula

$$
\Delta S_{d y n}=\mu \frac{d}{E} \sigma_{p u l}(t)\left(1+Q_{c} \frac{F_{k}}{F_{s . d}}\right),
$$

where $F_{s . d}$ is the section area of a part conjugate to a part loaded with an impact.

For a normal operation of a movable joint the smallest structure gap $S_{K \min }$ (Fig. 2) must be larger than a total value of diametral deformations of the shaft $\Delta d$ and hole $\Delta D$

$$
S_{K \min } \geq \Delta d+\Delta D .
$$

If condition (6) is not met and the initial structural gap is reduced, then instead of the provided gap an interference fit is formed in the joint, and the quench of joint's details may appear. In order to avoid such effects, condition (6) must be met, including when push loadings of greater amplitude occur and under the influence of other factors.

In this regard, we rewrite inequality (6) in the following form

$$
S_{\min }=\Delta d+\Delta D+k_{s}\left(R Z_{d}-R Z_{D}\right),
$$

where $R Z_{d}$ and $R Z_{D}$ are heights of micro-asperities of surfaces of a shaft and a hole; $k_{s}$ is the safety factor of joint mobility.

Therefore, the minimum structure gap in the pistoncylinder joint, taking into account (5) and (7), is determined by the formula

$$
S_{\min }=\mu \frac{d_{p}}{E}\left(\sigma_{\max . p}+\sigma_{\max . c}\right)+k_{s}\left(R a_{p}+R a_{c}+2\right),
$$

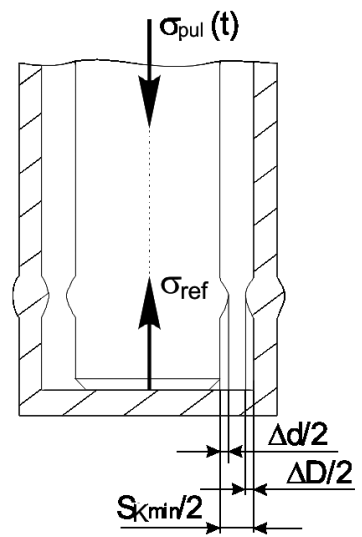

Fig. 2. Scheme of a gap change in a joint during an impact where $R a_{p}$ and $R a_{c}$ are the heights of micro-asperities of the piston and cylinder, $\mu \mathrm{m} ; d_{p}$ is piston diameter, $\mathrm{m} ; k_{s}$ is the safety factor of joint mobility.

In turn, based on the interference of stress waves, amplitudes are determined by the formula

$$
\left.\begin{array}{l}
\sigma_{\text {max. } p}=\sigma_{p}-\sigma_{c}+\sigma_{r e f} \\
\sigma_{\text {max.c }}=\sigma_{c}
\end{array}\right\} .
$$

According to the preliminary analysis, the safety factor, taking into account deviations of a load and velocity from the calculated values and the presence of particulate matter in the working fluid [9], can be taken equal to 2-2.5.

Taking into account the phenomenon of wear in the joints of hydraulic props. In the process of work of machines and mechanisms, including hydraulic props of the sections of powered supports, the nature of fits in the joints gradually changes due to the wear of surfaces of conjugated parts [6]. At the same time, gaps increase in movable joints. After a period of work, the wear of parts' surfaces in the joints reaches the limiting values at which further operation becomes economically inexpedient or technically unreliable, since operational factors sharply deteriorate with the loss of joint accuracy. In hydraulic props of the sections of powered supports large gaps in the joints lead to significant leaks of the working fluid, therefore, the values of nominal work resistances cannot be achieved [11].

A scheme of the formation of a gap in the piston joint of a hydraulic prop of a powered support is shown in Fig. 3.

The scheme shows that the maximum allowable gap in the joint is

$$
S_{t o l}=S_{\max }+T_{D o t}+T_{d o t}
$$

where $S_{\max }$ is the greatest structure (tabular) gap set by a designer depending on the specified fit; $T_{D o t}$ and $T_{d o t}$ are operating tolerances according to a hole and a shaft, designed to create the wear margin of conjugated surfaces.

Value $T_{S o t}=T_{D o t}+T_{d o t}$ is the operating tolerance of a fit. Then the formula (8) has the form

$$
S_{t o l}=S_{\max }+T_{S o t}
$$

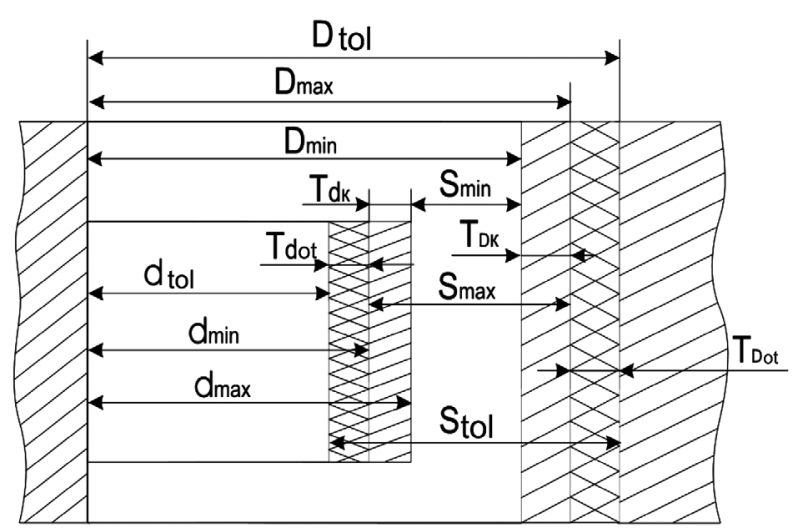

Fig. 3. Scheme of the formation of a gap in the piston joint of a hydraulic prop of a powered support 
With the linear law, the wear of the details of the joint can be written [9]

$$
T_{\text {Sot }}=\rho \sum \gamma,
$$

where $r$ is operational life of the joint, i.e. the joint's operating time to the maximum allowable wear, at which the efficiency of operation of a mechanism sharply decreases, h.; $\sum \gamma=\gamma_{D}+\gamma_{d}$ is the total wear rate of the joint, $\mu \mathrm{m} / \mathrm{h}$.

For cylindrical joints, the value of the maximum allowable gap is recommended to be determined from the ratio [10]

$$
S_{t o l}=K_{y} S_{o p t},
$$

where $K_{y}$ is the coefficient taking into account the conditions in the zone of friction contact; $S_{o p t}$ is an optimal gap in the joint.

Coefficient $K_{y}$ according to the performance data for various machines and joints, in particular for impact machines, can take values from 2.5 to 4.5 . The narrowing of this range requires further research on the study of influence of the main factors on a wear process [12].

Value $S_{\text {opt }}$ is also not sufficiently studied, except for rotating cylindrical joints, in which it is determined by the condition of creation of the minimum necessary lubricating layer. As a result of processing statistical data of studies of various authors [10] for various types of machines using the least squares method, we define the empirical dependence $S_{\text {opt }}$ of movable joints of hydraulic props of sections of powered supports

$$
S_{\text {opt }}=11.63+2.2 S_{\min },
$$

which allows, in the first approach, determining the maximum allowable gaps in the joints of hydraulic props of sections of powered supports. Then the expression (11) takes the form using the ratio (12)

$$
S_{t o l}=K_{y}\left(11.63+2.2 S_{\min }\right) .
$$

Let us evaluate the wear rate of steel parts during their relative displacement, taking into account friction effects. In the zone of frictional contact, complex nonstationary physical and chemical and mechanical processes occur, the random nature of which is determined by the ambiguous influence of many factors on the wear rate. These factors include properties of the contacting bodies and environments, surfaces' state, their roughness, value and nature of the load change, contact time, velocity and acceleration of motion, temperature upon contact, etc. [12].

Due to the impact of rock bursts on the sections of powered supports, an interest causes the influence of displacement velocity of the moving elements of hydraulic props on the wear of conjugated surfaces of piston joints. As a result of processing the experimental data of various studies for steel samples [10], an empirical expression was obtained according to a well-known method, reflecting the dependence of the wear rate on the velocity of relative displacement of steel parts (in $\mu \mathrm{m} / \mathrm{h}$ ) ranging from 0 to $2 \mathrm{~m} / \mathrm{s}$

$$
\gamma=90.32\left(10^{-3} V^{0.46}\right)
$$

Expression (14) was obtained for steel samples not subjected to heat and hardening treatment. Since two conjugated parts are involved in a friction joint, and the total wear rate is included in the formula (14), let us consider the process of interaction of parts from different materials of a friction pair.

Let us find out the influence of thermal and hardening processes on the wear rate of the conjugated parts of hydraulic props of the sections of powered supports. The literature [9] provides information about an increase of the wear resistance of a material by 10 times with an increase in hardness by 500 units HV (Vickers hardness). An increase in the hardness of steels with certain types of processing was evaluated:

- cementation and HFC treatment - 500-600 HV;

- nitriding - 800-1200 HV;

- chrome plating - 1200-1400 HV;

- plasma building-up by hard alloys - 1400$1600 \mathrm{HV}$.

For a conjugate pair, which is formed by sliding surfaces having different hardness and sizes of friction areas, the following two conditions can be determined [5]:

1. $(H V)_{1}>(H V)_{2} ; \quad F_{T 1}<F_{T 2}$.

2. $(H V)_{1}<(H V)_{2} ; \quad F_{T 1}<F_{T 2}$,

where $(H V)_{1}$ and $(H V)_{2}$ are hardness of rubbing surfaces; $F_{T 1}$ and $F_{T 2}$ are corresponding areas of friction surfaces.

A pair with an arrangement of materials that meets the first requirement is called a straight friction pair, while the one satisfying the second condition is called a reverse pair. For piston joints of hydraulic props of the sections of powered supports, it is advisable, from the point of view of efficiency, to take the "cylinder-piston" and "rod-bushing" pairs as reverse, due to the cost of manufacturing required parts.

Let us introduce the concept of the divisible factor of materials' wear rates of the sliding surfaces of two conjugated parts $K_{c}$

$$
K_{c}=\gamma_{\max } / \gamma_{\min }
$$

where $\gamma_{\max }$ and $\gamma_{\min }$ are, accordingly, the wear rate of materials of conjugated parts with higher and lower hardness.

From the expression (9), taking into account the expression (10), we get

$$
S_{\max }=S_{t o l}-\rho \sum \gamma .
$$

Substituting expressions $(16,13)$ into the expression (14), taking into account the expression (15), we obtain the formula for determining the maximum structural gaps in the movable joints of hydraulic props of the sections of powered supports

$$
\begin{aligned}
& S_{\max }=K_{y}\left(11.63+2.2 S_{\min }\right)- \\
& -90.32\left(10^{-3} \frac{1+K_{c}}{K_{c}} p V^{0.46}\right) .
\end{aligned}
$$

Thus, expressions are obtained for determining the minimum and maximum structural gaps in movable joints of hydraulic props, taking into account the wave 
dynamics of rock bursts and the wear of surfaces of conjugated parts during friction contacts in the process of operation of powered supports.

Results. Let us consider the application of the proposed method for two joints of a hydraulic prop: "piston-cylinder" and "rod-bushing". The calculation is based on the scheme presented in Fig. 1.

Let us choose the fit of movable joints for a hydraulic prop of the powered support "Glinik". For the production of calculations, we write out the initial data:

- elastic modulus $E=0.2 \cdot 10^{6} \mathrm{MPa}$

- Poisson's ratio $\mu=0.28$;

- piston diameter $d_{p}=0.16 \mathrm{~m}$;

- rod diameter $d_{r}=0.14 \mathrm{~m}$;

- piston length $L_{p}=1.4 \mathrm{~m}$;

- rod length $L_{r}=0.11 \mathrm{~m}$;

- safety factor of joint mobility $=2.1$;

- height of microasperities of a piston and a cylinder $R a_{p}$ and $R a_{c}=0.63 \mu \mathrm{m}$.

After substituting data into formula (6) and intermediate calculations, we obtain the minimum structure gap in the joint:

- "piston-cylinder" $-S_{\min 1}=41.3 \mu \mathrm{m}$;

- "rod-bushing" $-S_{\min 2}=43.2 \mu \mathrm{m}$.

Let us calculate the maximum structure gaps in these joints by the formula (17).

Life before the first overhaul is taken in accordance with SS 18585-73. The divisible factor of wear rates $k_{c}$ for both joints is 10 , i. e. we will think that the surfaces of the main parts of the reverse friction pairs (cylinder and rod) will have a hardness of about 10 times greater than the hardness of the parts conjugated with them (piston and bushing, respectively). This is achieved by chroming the surfaces of the main parts [13].

Then we obtain the maximum structure gap for a joint:

- "piston-cylinder" $-S_{\max 1}=207 \mu \mathrm{m}$;

- "rod-bushing" $-S_{\max 2}=240 \mu \mathrm{m}$.

According to ISO 286-2 we set standard fits, which most closely correspond to the calculated structure gaps [14].

For a joint "piston-cylinder" the fit

$$
\varnothing 160 \frac{H 9(+0.100)}{f 8\left(\begin{array}{l}
-0.043 \\
-0.106
\end{array}\right)}
$$

ensuring $S_{\min 1}=43 \mu \mathrm{m}$ and $S_{\max 1}=206 \mu \mathrm{m}$.

For a joint "rod-bushing" the fit

$$
\varnothing 140 \frac{H 9(+0.100)}{e 8\left(\begin{array}{l}
-0.085 \\
-0.148
\end{array}\right)}
$$

ensuring $S_{\min 1}=85 \mu \mathrm{m}$ and $S_{\max 1}=248 \mu \mathrm{m}$.

Based on the expression (17), it is possible to evaluate the life of the hydraulic prop's joints, as well as when supports exposed to rock blows of different intensity, expressed in the rate of rock collapse.

We transform the expression (17), expressing life of the joint as a function

$$
p=11.1 \frac{k_{c}}{1+k_{c}}\left[k_{y}\left(11.63+2.2 S_{\min }\right)-S_{\max }\right] \cdot \vartheta^{-0.46},
$$

where $\vartheta$ is the rate of rock burst, i. e. collapse rate of overlying rocks on the section of powered supports, $\mathrm{m} / \mathrm{s}$.

We will evaluate the life for the joint "piston-cylinder" of a hydraulic prop by taking a standard fit written above and changing the drift velocity of a rod in the range from 0 to $0.6 \mathrm{~m} / \mathrm{s}$, meaning that during a normal operation of a powered support the drift velocity is about $10^{-5} \mathrm{~m} / \mathrm{s}$, and during a rock burst up to $0.5 \mathrm{~m} / \mathrm{s}$ and above. The ratio of wear rates of the materials of a piston and a cylinder will be changed in the range from 1 to 9 (coefficient $k_{c}$ ).

The graphical dependences created by the formula (18) under the indicated conditions are shown in Fig. 4.

We will also evaluate the influence of the maximum structure gap of a joint at different velocities on the life of the joint (Fig. 5). The coefficient $\mathrm{k}_{\mathrm{c}}$ is assumed to be 10 .

Conclusions.

1. Dependencies were obtained, showing that during the normal operation of a powered support provided that rock bursts do not occur, the life of a hydraulic prop considerably exceeds the life specified by SS. The growth of a gap due to wear is determined mainly by maneuvering and support's displacement.

2. During rock pressure manifestation, depending on the drift velocity of the roof, the life set by SS may not be achieved. In all cases, it is advisable to increase the life by the proper selection of materials of conjugated parts, i.e. by the regulation of the coefficient $k_{c}$.
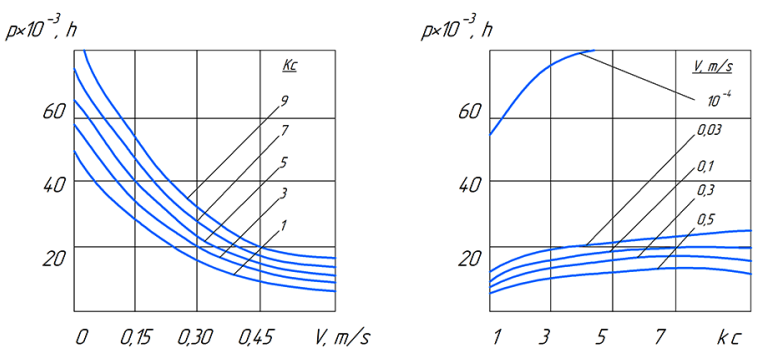

Fig. 4. Dependencies of the "piston-cylinder" joint's life on the drift velocity of the roof and the ratio of the rates of wear of the parts of the joint
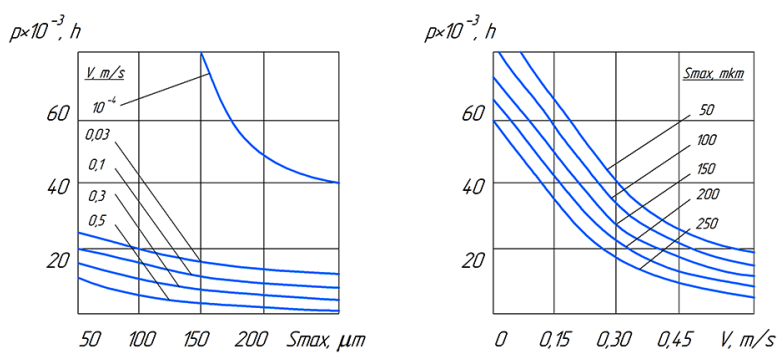

Fig. 5. Dependencies of the life of a "piston-cylinder" joint on the drift velocity of the roof and the maximum structure gap 
3. The proposed method allows predicting the life of joints of powered hydraulic props, taking into account the quality of manufacturing, operating conditions and the materials of parts, as well as issuing recommendations that increase their efficiency.

\section{References.}

I. Kuznetsov, V. V. (2015). Rock bump - the reason of methane out burst in the coal mine? Bulletin KRASEC. Phys. \& Math. Sci, 10(1), 30-38. DOI: 10.18454/23130156-2015-10-1-30-38.

2. Jixiong Zhang, Baiyi Li, Nan Zhou, \& Qiang Zhang. (2016). Application of solid backfilling to reduce hardroof caving and longwall coal face burst potential. International Journal of Rock Mechanics and Mining Sciences, 88, 197-205. DOI: 10.1016/j.ijrmms.2016.07.025. 3. Baranov, S.G., Vlasenko, D.S., \& Loginov, M.A. (2011). Dynamics of manifestation of rock pressure in the processing of flat coal seams with heavy roofs. Journal of mining institute, 190, 26-30.

4. Xuewen Wanga, Zhaojian Yanga, Jiling Fengb, \& Hunju Liua. (2013). Stress analysis and stability analysis on doubly-telescopic prop of hydraulic support. Engineering Failure Analysis, 32, 274-282. DOI: 10.1016/j. engfailanal.2013.04.006.

5. Buyalich, G. D., Buyalich, K. G., \& Voevodin, V.V. (2016). Radial Strains of Double-layer Cylinders in Hydraulic Props of Powered Supports. IOP Conf. Series: Materials Science and Engineering 127, 1-7 DOI: 10.1088/1757-899X/127/1/012034.

6. Zhetessova, G.S., Zharkevich, O.M., Buzauova, T. M., \& Pleshakova, Ye.A. (2013). Damage to the hydrovlic racks of mechanized supports and methods for their elimination. Bulletin of the KazNTU, 1, 8489.

7. Zhukov, I.A. (2008). Modification of the differential equations of the wave theory of longitudinal collision of rods. Bulletin of the Tomsk Polytechnic University, 313(2), 5-9.

8. Shahar Berger, G. Ben-Dor, \& Oren Sadot. (2015). Numerical Investigation of Shock Wave Attenuation by Dynamic Barriers. Journal of Fluids Engineering, 137(4), DOI: 10.1115/1.4028875.

9. Sung-Jae Kim, Weoncheol Koo, \& Min-Jae Shin. (2018). Numerical and experimental study on a hemispheric point-absorber-type wave energy converter with a hydraulic power take-off system Renewable Energy. DOI: 10.1016/j.renene.2018.09.097.

10. Tuna Eren. (2018). Kick tolerance calculations for drilling operations Journal of Petroleum Science and Engineering, 171, 558-569. DOI: 10.1016/j.petrol.2018.07.077.

11. Buyalich, G. D., Buyalich, K. G., \& Voyevodin, V.V. (2015). Radial deformations of working cylinder of hydraulic Legs depending on their extension. In IOP Conference Series: Materials Science and Engineering (pp.1-7). DOI:10.1088/1757-899X/91/1/012087.

12. Zia, U.A., \& Baqai, A.A. (2014). Washin Akram. Effect of Surface Roughness and Temperature on EHL for Parallel Surfaces Subjected to High Acceleration. Tribology in Industry, 36(2), 144-154.
13. Aimin Liang, Yuwen Li, Hongyu Liang, Liwei Ni, \& Junyan Zhang. (2017). A favorable chromium coating electrodeposited from $\mathrm{Cr}$ (III) electrolyte reveals antiwear performance similar to conventional hard chromium. Materials Letters, 189, 221-224.

14. ISO 286-2:2010 Basic norms of interchangeability. Geometrical product specifications. ISO code system for tolerances on linear sizes. Part 2: Tables of standard tolerance classes and limit deviations for holes and shafts (n.d.). Retrieved from http://bsfsh.com/upload/file/20 160601/20160601095795959595.pdf.

\section{Вибір посадок і прогнозування ресурсу роботи рухливих з'єднань гідростійок механізованого кріплення}

\author{
Г. С. Жетесова, О. М. Жаркевич, О.А. Нуржанова, \\ Д. С. Жунуспєков
}

Карагандинський державний технічний університет, м. Караганда, Республіка Казахстан, e-mail: zharkevich82@mail.ru

Мета. Встановлення залежностей конструктивних параметрів з урахуванням впливу динамічних процесів і явища зносу в рухомих з'єднаннях гідростійок механізованих кріплень для збільшення ресурсу їх роботи.

Методика. У роботі використані метод аналогів і розрахунковий метод при виборі посадок, розмірний аналіз при побудові схеми утворення зазору в поршневому з'єднанні гідростійки механізованого кріплення. Використаний метод найменших квадратів для визначення емпіричної залежності рухомих з'єднань гідростійок механізованих кріплень від мінімального конструктивного зазору та коефіцієнту запасу рухливості з'єднання.

Результати. Розроблена методика, що дозволяе прогнозувати ресурс з'єднань і в цілому гідростійок у залежності від якості виготовлення, умов експлуатації та матеріалів деталей. Розроблені рекомендації, що підвищують працездатність гідростійок механізованих кріплень.

Наукова новизна. Отримані вирази для визначення мінімального й максимального конструктивного зазору в рухомих з'єднаннях гідростійок, що враховують хвильову динаміку гірських ударів і зношування поверхонь сполучених деталей при фрикційних контактах у процесі роботи механізованих кріплень.

Практична значимість. Розроблено порядок проведення розрахунків конструктивного зазору задля прогнозування ресурсу роботи рухомих сполук гідростійки.

Ключові слова: механізоване кріплення, зазор, гідростійка, зношування, гірський удар

\section{Выбор посадок и прогнозирование ресурса работы подвижных соединений гидростоек механизированных крепей}

\author{
Г. С. Жетесова, О. М. Жаркевич, О. А. Нуржанова, \\ Д. С. Жунуспеков
}


Карагандинский государственный технический университет, г. Караганда, Республика Казахстан, е-mail: zharkevich82@mail.ru

Цель. Установление зависимостей конструктивных параметров с учетом влияния динамических процессов и явления износа в подвижных соединениях гидростоек механизированных крепей для увеличения ресурса их работы.

Методика. В работе использованы метод аналогов и расчетный метод при выборе посадок, размерный анализ при построении схемы образования зазора в поршневом соединении гидростойки механизированной крепи. Использован метод наименьших квадратов для определения эмпирической зависимости подвижных соединений гидростоек механизированных крепей от минимального конструктивного зазора и коэффициента запаса подвижности соединения.

Результаты. Разработана методика, позволяющая прогнозировать ресурс подвижных соедине- ний и в целом гидростоек в зависимости от качества изготовления, условий эксплуатации и материалов деталей. Разработаны рекомендации, повышающие работоспособность гидростоек механизированных крепей.

Научная новизна. Получены выражения для определения минимального и максимального конструктивного зазора в подвижных соединениях гидростоек, учитывающие волновую динамику горных ударов и изнашивание поверхностей сопряженных деталей при фрикционных контактах в процессе работы механизированных крепей.

Практическая значимость. Разработан порядок проведения расчетов конструктивного зазора для прогнозирования ресурса работы подвижных соединений гидростойки.

Ключевые слова: механизированная крепь, зазор, гидростойка, изнашивание, горный удар

Рекомендовано до публікації докт. техн. наук К. Т. Шеровим. Дата надходження рукопису 11.03.18. 